Jurnal Pemikiran Sosiologi Volume 5 No. 1, Januari 2018

\title{
Pekerja Migran dan Ekonomi Informal Ilegal (Prostitusi) \\ di Wilayah Pasar Kembang, Yogyakarta1
}

\author{
Odam Asdi Artosa ${ }^{2}$
}

\begin{abstract}
Abstraksi
Malioboro merupakan salah satu kawasan aktivitas perekonomian yang relatif besar khususnya yang berkaitan dengan industri pariwisata di Yogyakarta. Di kawasan tersebut dapat ditemui berbagai macam aktivitas ekonomi informal yang sudah ada sejak zaman kolonial, mulai dari pedagang kaki lima hingga prostitusi. Pasar Kembang adalah salah satu wilayah khusus pariwisata yang berlokasi di utara Malioboro memiliki keragaman praktik ekonomi informal dan diduga juga menjadi lokasi praktik ilegal prostitusi. Berangkat dari konteks itu, kajian ini bertujuan untuk melihat dinamika sektor informal yang bersifat ilegal seperti prostitusi khususnya yang diduga telah berlangsung di wilayah Pasar Kembang. Penelitian ini menggunakan metode pendekatan fenomenologi yang bertujuan untuk menyajikan suatu analisis mengenai aktivitas ekonomi informal yang bersifat ilegal dengan cara memperoleh informasi mendalam atau gambaran penjabarannya mengenai praktik prostitusi dari perspektif para informan yang terlibat dalam kajian ini. Hasil penelitian menunjukkan bahwa pekerja migran yang kesulitan mendapatkan pekerjaan di sektor formal dan juga praktik ekonomi informal yang legal harus menegosiasikan tekanan hidup karena kebutuhan ekonomi dengan memilih jalan pintas dalam praktik prostitusi ilegal.
\end{abstract}

Kata kunci: pekerja migran, aktivitas ekonomi informal, prostitusi.

\begin{abstract}
Malioboro is a wellknown zone for its large economic activities, especially those dealing with tourism industry in Yogyakarta. In the tourist zone of Malioboro, varieties of informal economic activities ranging from street vendors to prostitution can be found and such activities have been existed even since the colonial era. Pasar Kembang is a particular tourist sub district located in northern zone of Malioboro that has a diversity of informal economic practices and is also presumed to be the site of illegal practice for prostitution. Departing from such context, this study aims to see the dynamics of the illegal informal sector such as the practice of prostitution, especially which presumably have been occurred in Pasar Kembang. This research applied a phenomenology approach method in order to provide an analysis of illegal informal economic activities by gaining a deep information or the description on the practices of prostitution from the perspective of the informants involved in this study. The result of the research shows that migrant workers who have difficulty in finding jobs in the formal sector and or legal informal practices have to negotiate their pressures of economic necessity by simply enter a shortcut to the illegal practices of prostitution.
\end{abstract}

Keywords: migrant worker, informal economic activities, prostitution.

\section{A. Pengantar}

Dewasa ini, isu tentang prostitusi menjadi topik yang hangat diperbincangkan, karena keberadaaannya menimbulkan pro dan kontra dalam masyarakat. Disatu sisi, prostitusi memliki implikasi terhadap pengaruh moral dan nilai-nilai sosial lainnya, namun disisi lain prostitusi mampu memberikan pemasukan ekonomi bagi para pelibat kegiatan tersebut (Sugiyono, dkk 2015:4). Namun, di beberapa daerah seperti Surabaya dan Jakarta, prostitusi dibubarkan dan direlokasi, misalnya: Dolly, Jarak dan Kalijodo (Cahya, 2016).

\footnotetext{
1 Untuk mengutip artikel ini: Artosa, Odam Asdi. 2018. 'Pekerja Migran dan Ekonomi Informal Ilegal (Prostitusi) di Wilayah Pasar Kembang,Yogyakarta'. Jurnal Pemikiran Sosiologi 5 (1): 21-36

${ }^{2}$ Odam Asdi Artosa adalah mahasiswa pascasarjana program studi Master of Arts (MA) di Dept. Sosiologi, Fisipol UGM.
} 
Jurnal Pemikiran Sosiologi Volume 5 No. 1, 2018

Pekerja Migran dan Ekonomi Informal Ilegal (Prostitusi) di Wilayah Pasar Kembang, Yogyakarta

Odam Asdi Artosa

Menurut Keith Hart (dalam Manning dan Effendi, 1985:79-81) prostitusi termasuk dalam jasa kegiatan perekonomian di sektor informal ilegal karena kegiatan tersebut bertentangan dengan peraturan hukum. Yogyakarta merupakan salah satu contoh perkotaan yang memiliki kegiatan sektor informal ilegal seperti prostitusi di Pasar Kembang. Pasar Kembang merupakan sebuah lokasi prostitusi yang sudah berjalan sejak masa kolonial (Prastya dan Darma, 2011:19). Menurut Mudjijono (2005:95) Pasar Kembang telah menjadi buffer zone bagi masyarakat sekitar kawasan karena mampu memberikan penghasilan tambahan.

Lokasi Pasar Kembang sebagai sebuah prostitusi cukup menarik, karena letaknya berada di dalam perkampungan. Meskipun begitu, masyarakat di kampung tersebut juga tidak keberatan dengan keberadaan prostitusi Pasar Kembang, justru masyarakat merasa diuntungkan karena rumahnya dapat disewakan kepada pengelola losmen untuk dijadikan tempat kegiatan prostitusi (Mudjijono, 2005:5). Namun, disisi lain kelompok masyarakat kampung yang berdekatan justru memasang pagar sebagai tanda batas wilayah fisik. Kondisi tersebut dibuktikan dengan adanya demarkasi pada setiap gang yang menghubungkan jalan antara dua wilayah itu.

Penelitian ini berfokus pada sektor informal ilegal karena sektor informal ilegal memiliki memiliki paradoks. Di satu sisi, sektor informal ilegal merupakan kegiatan ekonomi yang mampu memberikan pendapatan untuk pelakunya, tetapi kegiatan ini sangat bertentangan dengan peraturan hukum di Indonesia. Apalagi, status Indonesia sebagai negara hukum mempertegas penerapan hukum yang ada. Apabila penegakan hukum ditegaskan dan kegiatan sektor informal ilegal diberikan tindakan, maka hal ini dapat mengancam pendapatan beberapa pelaku, termasuk para pekerja migran.

Berdasarkan uraian di atas, penelitian ini bertujuan untuk mengetahui dinamika interaksi sosial ekonomi sektor informal ilegal di Pasar Kembang. Peneliti memilih Pasar Kembang sebagai lokasi penelitian karena di sana terdapat aktivitas sektor informal ilegal. Pendekatan yang digunakan ialah kualitatif karena peneliti ingin mengetahui dinamika interaksi sosial ekonomi yang dibentuk pelaku sektor informal ilegal. Dalam mengkaji permasalahan tersebut, peneliti menelusurinya dengan melakukan wawancara mendalam, pengamatan dan melakukan studi pustaka terhadap hasil penelitian terdahulu.

\section{B. Metode Penelitian}

Penelitian ini menggunakan pendekatan kualitatif dengan wawancara, studi pustaka dan pengamatan sebagai pedoman pengumpulan data. Metode yang digunakan adalah fenomenologi untuk memahami fenomena sosial berdasarkan kondisi sosiodemografis dari sudut pandang para informan. Lokasi dalam penelitian ini adalah Pasar Kembang Yogyakarta, yang meliputi Kampung Sosrowijayan Kulon. Teknik pemilihan informan dalam penelitian ini adalah teknik purposive snowball. Purposive snowball dilakukan dengan cara memenmui informan kunci, setelah itu peneliti mendapatkan rekomendasi informan lainnya untuk diwawancarai. Jenis data dalam penelitian ini adalah data primer dan data sekunder. Data primer diperoleh dari wawancara dan pengamatan, sedangkan data 
Jurnal Pemikiran Sosiologi Volume 5 No. 1, 2018

Pekerja Migran dan Ekonomi Informal Ilegal (Prostitusi) di Wilayah Pasar Kembang, Yogyakarta

Odam Asdi Artosa

sekunder diperoleh dari studi pustaka yang dilakukan oleh peneliti. Teknik pengumpulan data dalam penelitian ini dilakukan dengan wawancara, pengamatan dan penelusuran literatur terkait isu sektor informal ilegal.

Peneliti mengalami beberapa kendala saat pengumpulan data, antara lain pengurusan izin dan pencarian calon informan dari sektor informal ilegal. Disisi lain, peneliti memiliki kemudahan, yaitu faktor kekerabatan dengan beberapa elemen masyarakat yang biasa berada di Pasar Kembang. Meskipun mendapati banyak kendala, penelitian ini mendapati informasi mendalam dari enam orang informan kunci yang memenuhi kriteria untuk penggalian informasi dan data dalam penelitian ini. Adapun keenam informan kunci itu dideskripsikan dengan inisial nama untuk menjaga privasi informan itu sendiri sebagaimana yang menjadi dasar etis dalam penelitian ini dan disepkati oleh para informan. Adapun keenam informan tersebut dideskripsikan berdasarkan latar belakang keterlibatan mereka di dalam praktik ekonomi informal di Pasar Kembang. Sebagai berikut deskripsinya:

1. Ibu SRM (49 tahun), merupakan salah seorang pedagang makanan (2008sekarang) di Pasar Kembang yang dulunya pernah bekerja sebagai pekerja seks (19982008).

2. Ibu NVI (47tahun), merupakan seorang perempuan yang telah 5 tahun menjadi mucikari di Pasar Kembang dan dulunya pernah bekerja sebagai pekerja seks.

3. Bapak SRJ (63 tahun), merupakan ketua RW C di Sosrowijayan Kulon sekaligus tokoh masyarakat di Pasar Kembang.
4. Ibu IPG (47 tahun), adalah perempuan yang memiliki usaha dalam bidang jasa penginapan dan merupakan ketua RW B di kampung Sosrowijayan Wetan.

5. Bapak ED (47 tahun), merupakan seorang pengusaha losmen di Sosrowijayan Wetan.

6. Mbak WTI (40 tahun), merupakan pekerja seks di Pasar Kembang yang telah bekerja selama 3 tahun.

Teknik pengolahan data dilakukan dengan mengolah data transkrip hasil wawancara dari audio menjadi tekstual, sedangkan penggunaan data yang bersumber dari literatur dipilah dan diambil sesuai kebutuhan peneliti sebagai data tambahan terhadap data primer yang ditemukan di lapangan. Sementara itu, teknik analisis data yang digunakan dalam penelitian ini adalah analisis deskriptif interpretatif yang dilakukan dengan menceritakan kembali kejadian-kejadian yang dialami informan, lalu mengaitkan hasil interpretasi atas narasi informan dengan data-data lainnya seperti data kependudukan, serta menganalisis gabungan data deskriptif dengan data kependudukan.

\section{Perkembangan Pasar Kembang dalam Industri Pariwisata dan Ekonomi Informal Ilegal (Prostitusi)}

Pasar Kembang yang terletak di tengah perkotaan memiliki segala keunggulan fasilitas, aksesibilitas dan jaringan. Perkembangan pembangunan dan modernisasi mendorong daerah tersebut menjadi semakin ramai. Amalia (2013:469) menambahkan bahwa keramaian di lokasi prostitusi memberikan keuntungan bagi masyarakat sekitar. 
Jurnal Pemikiran Sosiologi Volume 5 No. 1, 2018

Pekerja Migran dan Ekonomi Informal Ilegal (Prostitusi) di Wilayah Pasar Kembang, Yogyakarta

Odam Asdi Artosa

Pasar Kembang atau lebih sering disebut Sarkem merupakan sebuah wilayah yang terletak di jantung Kota Yogyakarta. Pasar Kembang berdiri bersamaan dengan zaman kolonialisasi Belanda. Ferry Ardiyanto dalam laman web Kemendikbud (2013) menambahkan bahwa berdasarkan Gouvernement Besluit No.9 tahun 1893 tanggal 20 April 1893, diputuskan bahwa akan dibangun jalur kereta api Yogyakarta - Brosot, yang merupakan jalur trem NISM dari jalur utama Semarang dan wilayahwilayah daerah kerajaan (Vorstelanden).

Setelah adanya proyek pembangunan rel kereta api, kawasan ini semakin kentara dengan kegiataan prostitusi. Menurut Prastya dan Darma (2011:19), pembangunan jalur kereta dari Batavia, Bogor, Cianjur, Bandung, Cilacap, Yogyakarta, dan Surabaya, menimbulkan kegiatan prostitusi di daerah sentral yang menjadi proyek pembangunan jalur kereta api. Kegiatan buruh rel kereta api membuat mereka jenuh, sehingga ketika mereka memiliki waktu luang selalu digunakan untuk mencari hiburan. Begitu pula dengan tentaratentara Belanda, hiburan yang paling sering dicari kala itu salah satunya ialah hubungan seksual. Pada akhirnya, Pasar Kembang mulai diramaikan dengan perempuan-perempuan penghibur. Saat itu, perempuan pertama kali yang menjadi sosok terkenal sebagai pekerja seks adalah Ibu Rumiyati, seorang mata-mata tentara Indonesia yang ditugaskan untuk memata-matai Belanda.

Pasca kemerdekaan, Sosrowijayan mulai terbagi menjadi dua, yaitu Sosrowijayan Kulon dan Sosrowijayan Wetan. Pembagian wilayah tersebut diberikan Sri Sultan Hamengku Buwono IX (HB IX) untuk kerabat dari trah Sri Sultan Hamengku Buwono VII (HB VII) yaitu Ndoro Kanjengan dan
Ndoro Ayu. Setelah terbagi menjadi dua bagian, perkembangan pembangunannya pun cenderung berbeda, meskipun masih sama-sama sebagai kampung wisata. Sosrowijayan Wetan terkenal dengan kampung wisata internasional karena domain pengunjungnya adalah turis, sedangkan, Sosrowijayan Kulon terkenal dengan wisata malam. Perkembangan Pasar Kembang dalam hal prostitusi tampaknya menyita perhatian tersendiri bagi pemerintah daerah yang dibuktikan dengan adanya peraturan daerah No. 15/1954 tentang penutupan rumah-rumah pelacuran. Adanya peraturan tersebut tampaknya tidak banyak berpengaruh pada kegiatan pelacuran di Pasar Kembang. Hull dkk dalam Mudjijono (2005:26) menyebutkan bahwa aktivitas pelacuran menumbuhkan aktivitas lain seperti pembangunan penginapan dan fasilitas lainnya, dimana keduanya meningkat secara bersamaan. Pertumbuhan warung-warung kecil dan toko kelontong mengiringi pesatnya perkembangan prostitusi di Pasar Kembang.

Pada tahun 1970-an, Pasar Kembang semakin terkenal dengan sebutan Pasar Kembang Mbalokan. Nama Mbalokan sendiri menurut Koeswinarno (2004:35-36) digunakan karena tepat di utara Pasar Kembang merupakan tempat meletakkan balokbalok kayu besar yang digunakan sebagai bahan bakar kereta api. Pesatnya pertumbuhan aktivitas perekonomian dan jumlah perempuan-perempuan penyaji seks saat itu membuat pemerintah daerah semakin pilu dengan keadaan di sana. Masalahnya, kampung Sosrowijayan telah berkembang menjadi pasar yang menyajikan bisnis gelap prostitusi. Akhirnya, pada tahun 1974, kepala daerah saat itu mengambil tindakan preventif dengan mengeluarkan keputusan kepala daerah No. 
Jurnal Pemikiran Sosiologi Volume 5 No. 1, 2018

Pekerja Migran dan Ekonomi Informal Ilegal (Prostitusi) di Wilayah Pasar Kembang, Yogyakarta

Odam Asdi Artosa

166/K.D/1974 tentang penunjukan tempat untuk proyek resosialisasi wanita tuna susila di Yogyakarta, dengan mengambil tempat pelaksanaan di sebelah selatan Desa Mrican (Mudjijono, 2005:28).

Upaya pemerintah untuk melakukan penataan kota, khususnya wilayah kumuh dan hunian liar (squatters) terus dilakukan. Squatters atau yang sering disebut oleh Effendi (1995:125) sebagai "daerah hitam", adalah sebuah lokasi yang digunakan sebagai tempat operasi pelacur, germo, dan gali (gabungan anak liar). Mudjijono (2005:29) menuturkan bahwa pada tahun 1976, mucikari serta pelacur-pelacur di Pasar Kembang berhasil dipindahkan dari pasar Kembang ke daerah selatan Desa Mrican. Penduduk pendatang yang dibawa ke Desa Mrican ini bukan Pekerja Seks dan Mucikarinya saja, tetapi ada juga gelandangan dan pengemis.

Kemudian setelah resosialisasi berjalan cukup lama, pada tahun 1997 Walikota Yogyakarta mengeluarkan Keputusan Nomor: 408/KD/Tahun 1997 tentang pencabutan keputusan Walikota Yogyakarta No. 166/K.D/1974 tentang penunjukan tempat untuk proyek resosialisasi wanita tuna susila. Otomatis, keadaan ini menyebabkan mucikari dan pelacur kembali lagi ke Pasar Kembang. Pada tahun 1997, Pasar Kembang mulai ramai lagi. Sejak kembali beroperasinya Pasar Kembang pada tahun 1997, jumlah losmen-losmen untuk pekerja seks hanya berada pada sisi utara Sosrowijayan Kulon saja. Setelah banyaknya pekerja seks, bisnis losmen mulai berkembang dan merambat ke sisi selatan Sosrowijayan Kulon. Pernyataan ini diperkuat oleh penjelasan Ibu SRM yang menegaskan bahwa penutupan tempat resosialisasi di Desa Mrican mengakibatkan Pasar Kembang kembali lagi menjadi sentral prostitusi, meskipun saat itu lokasinya belum seluas saat ini. Keramaian Pasar Kembang sebagai lokasi prostitusi dimanfaatkan oleh masyarakat sekitar untuk membuka usahausaha yang menghasilkan nilai rupiah.

Di masa kini, ketika menyeruak masuk di gang-gang sempit kawasan Pasar Kembang, merefleksikan aroma kehidupan malam khas Yogyakarta yang tidak asing terdengar di telinga masyarakat. Bagi penduduk asli, Pasar Kembang merupakan tempat tinggal sekaligus lahan bisnis yang memberikan mereka limpahan pemasukan. Pasar Kembang yang lebih sering disebut Sarkem karena di dalamnya tersaji kegiatan prostitusi yang memperdagangkan perempuan-perempuan penjaja tubuh yang dianalogikan sebagai sebuah kembang.

Sosrowijayan Kulon dikenal sebagai kampung wisata malam karena aktivitasnya menyajikan jajanan pada malam hari. Jajanan dalam konteks ini sebagai sebuah dagangan yang menjual seksualitas tubuh perempuan. Setiap hari sekitar pukul 20.00 WIB ke atas, aktivitas ini sudah mulai terlihat. Perempuan-perempuan pekerja seks mulai tethek di depan losmen sepanjang jalan Sosrowijayan Kulon. Memang, losmen-losmen di Sosrowijayan Kulon hanya digunakan untuk ngamar langsiran , sehingga seluruh pelayanan dilakukan di dalam losmen. Ngamar langsiran adalah istilah dalam bahasa Jawa yang berarti menyewa kamar losmen tetapi dalam waktu yang singkat. Biasanya hanya untuk berhubugan seks saja, tidak untuk beristirahat melepas letih. Meskipun begitu, tidak menutup kemungkinan bahwa pengelola losmen juga mengantar pekerja seksnya ke hotel-hotel di luar Sosrowijayan Kulon, apabila ada panggilan dari luar. Pengelola losmen adalah orang yang menyewa 
Jurnal Pemikiran Sosiologi Volume 5 No. 1, 2018

Pekerja Migran dan Ekonomi Informal Ilegal (Prostitusi) di Wilayah Pasar Kembang, Yogyakarta

Odam Asdi Artosa

sebuah rumah dari seorang warga asli (pemilik losmen) dan menyewakan kamar untuk pekerja seks (PS). Pengelola losmen berbeda dengan germo ataupun mucikari. Pengelola losmen hanya meminta bayaran pada pekerja seks apabila memakai kamar untuk melayani pelanggan. Sedangkan mucikari atau germo meminta bayaran pada pekerja seks dalam periode tertentu sebagai biaya pengganti untuk mucikari atau germo tersebut karena sudah menampung pekerja seks dalam satu rumah dan memberinya makan.

Pada malam hari, sekitar pukul 20.00 WIB ke atas, memasuki kawasan Sosrowijayan Kulon tidaklah gratis. Seluruh pintu masuk dijaga oleh petugas keamanan yang berjaga menggunakan box besar (sebutan untuk sebuah kotak yang dipakai memberi tarikan pada tiap pengunjung) untuk meletakkan uang keamanan sebesar Rp.5.000,00. Selain tarikan kepada pengunjung, elemen-elemen lain juga dikenai biaya ini, seperti pekerja seks (PS), potang , bank plecit, pengelola losmen, dan sebagainya. Tarikan adalah retribusi yang dikenakan kepada seluruh pelaku usaha yang mencari nafkah di Sosrowijayan Kulon. Potang merupakan pelaku usaha sejenis rentenir yang meminjamkan pinjaman uang dengan bunga pengembalian 20\%. Peminjam yang telat mengembalikan akan dikenai denda dan ditambahkan sisa pinjaman yang belum lunas, kemudian jumlah tersebut dikenai lagi bunga sebesar 20\%. Kondisi tersebut berakumulasi sampai peminjam dapat melunasi semua hutangnya. Bank plecit merupakan pelaku usaha yang menawarkan barang atau uang yang menggunakan cara pembayaran cicilan setiap hari. Berbeda dengan potang, bunga yang diberikan bank plecit tidak dapat beranak dan bertambah.
Foto-foto dalam Gambar 1 menunjukkan kondisi rumah yang disewa oleh Ibu NVI untuk usaha losmennya. Setiap harinya, kamar yang digunakan untuk melayani pelanggan hanya satu, sedangkan satunya lagi adalah kamar pribadi yang digunakan Ibu NVI dan gandhengan-nya. Gandhengan adalah istilah yang digunakan untuk pasangan laki-laki dari pekerja seks yang bertindak sebagai suami. Selanjutnya, apabila melihat Sosrowijayan Kulon pada siang hari, biasanya perempuan yang menjajakan diri berusia cukup tua, yaitu kurang lebih usia 35 tahun keatas. Hal ini terjadi karena pada malam hari, perempuan yang berusia sudah tua kalah bersaing dengan perempuan yang masih muda.

\begin{tabular}{|c|l|c|c|}
\hline No. & \multicolumn{1}{|c|}{ Pembeda } & Dulu (Awal 1998) & Sekarang (2016) \\
\hline 1 & $\begin{array}{l}\text { Luas Wilayah Losmen } \\
\text { langsiran(1) }\end{array}$ & $\begin{array}{c}\text { Hanya bagian } \\
\text { depan } \\
\text { Sosrowijayan } \\
\text { Kulon }\end{array}$ & $\begin{array}{c}\text { Sampai ke belakang Sosrowijayan } \\
\text { Kulon }\end{array}$ \\
\hline 2 & Retribusi pengunjung & Rp2,000,00 & Rp5.000,00 \\
\hline 3 & Pengunjung & Banyak & Sedikit \\
\hline 4 & Karaoke & Tidak ada & Ada \\
\hline 5 & Jongos(2) & Adda & Tidak Ada \\
\hline 6 & $\begin{array}{l}\text { Tempat tethek Pekerja } \\
\text { Seks(3) }\end{array}$ & Didalam losmen & Diluar losmen \\
\hline 7 & Outlet kondom & Tidak ada & Ada \\
\hline
\end{tabular}

\section{Tabel 1. Perbedaan situasi awal 1998 dan 2016 di Sosrowijayan Kulon}

Keterangan: (1) Langsiran: adalah kata yang digunakan warga untuk menyebut istilah short time; (2) Jongos: adalah orang yang mencarikan pekerja seks sesuai kriteria yang diminta pelanggan (3) Tethek: adalah aktivitas duduk-duduk di pinggir losmen yang dilakukan pekerja seks untuk mencari pelanggan

(Sumber: Data primer, Odam Asdi Artosa 2016.) 


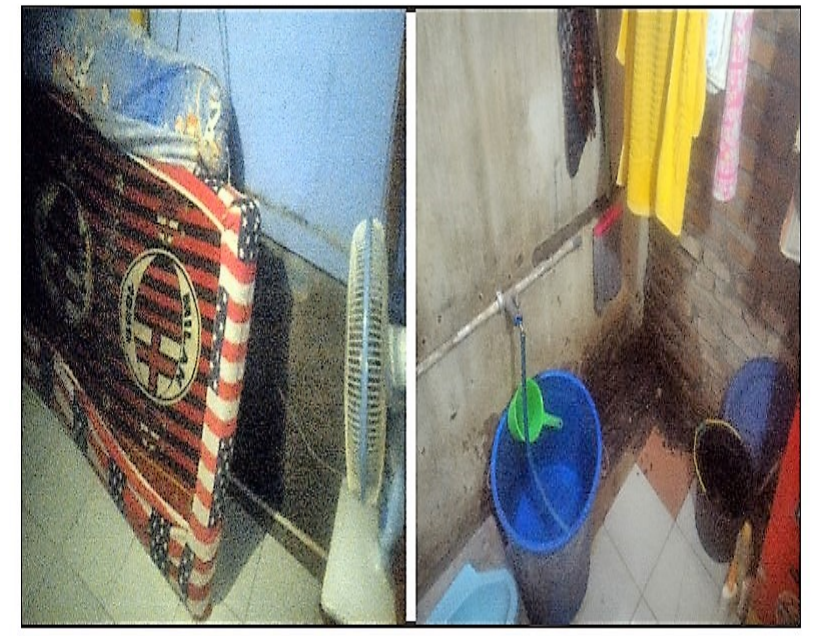

Gambar 1. Kondisi kamar langsiran (kiri) dan kamar mandi (kanan) di losmen Ibu NVI

(Sumber: Data Primer, Odam Asdi Artosa 2016)

Seiring dengan waktu yang terus berjalan, Pasar Kembang mengalami perubahan dari berbagai macam aspek. Perubahan sendiri diartikan oleh Usman (2015) sebagai imbas dari proses ekspansi dan intervensi pelbagai bentuk kapitalisasi yang hadir bersama dengan arus globalisasi. Saat ini, di Pasar Kembang, khususnya Sosrowijayan Kulon, hampir semua rumah telah dijadikan tempat usaha losmen langsiran. Tidak hanya itu, bentuk bangunan losmen langsiran di Sosrowijayan Kulon juga mengalami perkembangan. Hal tersebut dapat dilihat pada Tabel 1 .

Tabel 1 menunjukkan beberapa hal yang membedakan praktik ekonomi informal di Pasar Kembang berdasarkan kondisi di masa lalu dengan saat ini. Salah satu perubahan yang dapat diamati adalah luas losmen langsiran yang ada di Kampung Sosrowijayan Kulon. Losmen langsiran yang dulunya hanya berada pada bagian depan saja, yaitu bagian utara Kampung Sosrowijayan Kulon telah berkembang sampai ke bagian belakang. Selain itu, saat ini kesehatan organ reproduksi dari pekerja seks juga diperhatikan, terbukti melalui adanya pemeriksaan rutin dari Komisi Penanggulangan AIDS (KPA) kepada para pekerja seks serta pemberian kondom gratis oleh KPA Kota Yogyakarta. Kemudahan mendapatkan pekerjaan di sektor informal ilegal mendorong banyak pihak ingin terlibat di dalamnya (Mudjijono 2005:127). Tabel 2 menunjukkan jenis usaha sektor informal ilegal di Pasar Kembang. Berdasarkan jenis usaha, dapat diketahui pelaku dalam sektor informal ilegal di Pasar Kembang.

\begin{tabular}{|l|l|l|l|}
\hline N0 & Jenis Usaha & Jumlah & $\begin{array}{l}\text { Presentase } \\
(\%)\end{array}$ \\
\hline 1 & Pekerja Seks \&ladies club (1) & 283 & $73 \%$ \\
\hline 2 & losmen langsiran(2) & 40 & $10 \%$ \\
\hline 3 & Keamanan & 33 & $8 \%$ \\
\hline 4 & Karaoke & 20 & $5 \%$ \\
\hline 5 & Potang (3) & 13 & $3 \%$ \\
\hline 6 & Jumlah & 389 & $100 \%$ \\
\hline
\end{tabular}

Tabel 2. Jenis usaha sektor informal liegal di Pasar Kembang

Keterangan: (1) Ladies Club (LC): adalah perempuan yang hanya menemani pengunjung untuk menyanyi di karaoke); (2) Langsiran: adalah kata yang digunakan warga untuk menyebut istilah short time; (3) Potang : adalah kata yang sering digunakan warga untuk menyebut istilah lintah darat. Potang memberi pinjaman uang dengan bunga sebesar 20\% dari jumlah pinjaman

(Sumber: Data primer, Odam Asdi Artosa 2016) 
Jurnal Pemikiran Sosiologi Volume 5 No. 1, 2018

Pekerja Migran dan Ekonomi Informal Ilegal (Prostitusi) di Wilayah Pasar Kembang, Yogyakarta

Odam Asdi Artosa

Pekerja seks menjadi pelaku sektor informal ilegal yang banyak digeluti karena pekerja seks menjadi komoditas utama sektor informal ilegal di Pasar Kembang. Tabel 3 menunjukkan jenis dan tarif pada variasi pelayanan yang diberikan oleh pekerja seks di Pasar Kembang. Berdasarkan tabel 3, ada beberapa layanan yang diberikan pekerja seks. Tarif pelayanan yang diberikan oleh pekerja seks bersifat dinamis, tergantung kesepakatan antara pekerja seks dan pengunjung. Tabel 3 merupakan gambaran rentang harga terendah dan tertinggi dari kasus yang dialami oleh salah satu informan, Mbak WTI.

\begin{tabular}{|c|l|c|}
\hline No. & \multicolumn{1}{|c|}{ Jenis Pelayanan } & Tarif \\
\hline 1 & Hubungan seksual short time & $\mathrm{Rp} 100.000,00-\mathrm{Rp} 300.000,00$ \\
\hline 2 & Hubungan seksual per jam & $\mathrm{Rp} 350,000,00-\mathrm{Rp} 500.000,00$ \\
\hline 2 & Menemani karaoke & $\mathrm{Rp} 50.000,00-\mathrm{Rp} 150.000,00$ \\
\hline 3 & Menemani berbincang & $\mathrm{Rp} 50,000,00-\mathrm{Rp} 100,000,00$ \\
\hline
\end{tabular}

Tabel 3. Jenis dan tarif pelayanan pekerja seks

(Sumber: Data primer, Odam Asdi Artosa 2016)

Dalam memberikan pelayanan hubungan seks, setiap pekerja seks memasang tarif yang berbedabeda. Berdasarkan hasil wawancara dengan Ibu NVI, ada beberapa faktor yang menjadi pertimbangan pekerja seks dalam memasang tarif, yaitu durasi waktu, ramai/tidaknya Pasar Kembang, umur pekerja seks (umur yang menjadi favorit adalah stwatau setengah tua - istilah bagi para pekerja seksual usia pertengahan), serta ketertarikan pada calon pengunjung. Ciri-ciri lain dari pekerja seks di Pasar Kembang adalah migran dari luar Kota Yogyakarta dan bekerja di sektor informal ilegal Pasar Kembang karena masalah perekonomian dan pendidikan. Menurut Michael Lipton (dalam Varshney, 1993) permasalahan sektor informal ilegal karena adanya industrialisasi di perkotaan namun tidak mampu terserap dalam sektor formal perindustrian. Oleh karena itu strategi survival yang dilakukan adalah melakukan aktivitas informal ilegal di daerah hitam, hal ini dilakukan karena mereka tidak memiliki bekal yang cukup (Effendi, 1995).

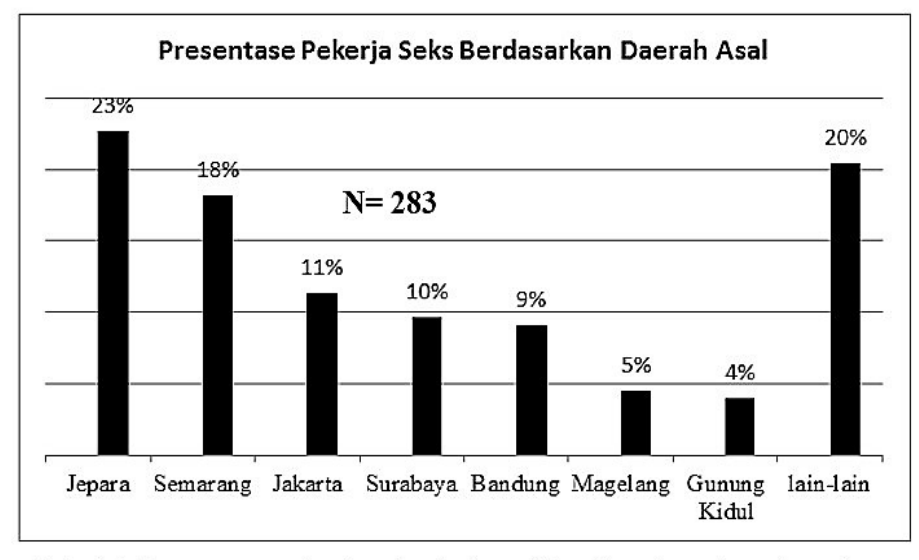

Tabel 4. Persentase pekerja seks (migran) berdasarkan daerah asal

(Sumber: Data primer, Odam Asdi Artosa 2016)

Berdasarkan Tabel 4, Provinsi Jawa Tengah menjadi penyumbang pekerja seks terbesar di Pasar Kembang dengan total persentase $46 \%$. Persoalan kemiskinan dan rendahnya pendidikan tidak mampu menolong para pelaku untuk masuk dalam lapangan kerja sektor formal. Menurut Nazara dalam bukunya yang diterbitkan oleh ILO (2010), gejala ini adalah ruang tunggu bagi para migran yang tidak diterima di sektor formal.

Sementara itu, dalam praktik ekonomi informal untuk jasa keamanan terdapat sistem yang disebut dengan istilah tarikan kepada para pelaku sektor informal ilegal lainnya di Pasar Kembang yang dilakukan dua kali dalam satu bulan. Setiap tarikan dikenakan biaya sebesar Rp100.000,00. Selain itu ada juga yang bertugas menarik retribusi kepada pengunjung sebesar Rp5.000,00. Sedangkan dalam praktik ekonomi ilegal para pengelola losmen langsiran bertindak sebagai Mamah dan 
Jurnal Pemikiran Sosiologi Volume 5 No. 1, 2018

Pekerja Migran dan Ekonomi Informal Ilegal (Prostitusi) di Wilayah Pasar Kembang, Yogyakarta

Odam Asdi Artosa

menyediakan kamar bagi para pekerja seks yang mendapatkan tamu. Panggilan ini disesuaikan dengan jenis kelamin pengelolanya. Jika pengelolanya laki, biasanya dipanggil Papah atau Bapak. Mamah merupakan orang yang mengelola losmen.

\begin{tabular}{|l|l|l|l|}
\hline No & RT & Jumlah Bangunan di RW C & Persentase \\
\hline 1 & RT 14 & 23 & $35 \%$ \\
\hline 2 & RT 15 & 9 & $14 \%$ \\
\hline 3 & RT 16 & 16 & $25 \%$ \\
\hline 4 & RT 17 & 17 & $26 \%$ \\
\hline & Jumlah & 65 & $\mathbf{1 0 0} \%$ \\
\hline
\end{tabular}

Tabel 5. Jumlah bangunan di RW C Sosrowijayan Kulon Sumber: Data primer, Odam Asdi Artosa 2016.

Tabel 5 menjelaskan tentang jumlah seluruh bangunan yang terdapat di RW C Sosrowijayan Kulon yaitu ada 65 bangunan. Untuk kepentingan penelitian, wilayah RW tersebut diganti dengan identifikasi RW C dimana terdapat praktik ekonomi informal termasuk yang bersifat ilegal. Kondisi dan fungsi dari bangunan tersebut yang berkenaan dengan praktik ekonomi informal ilegal dideskripsikan dalam Tabel 6 berupa tabulasi gambar.

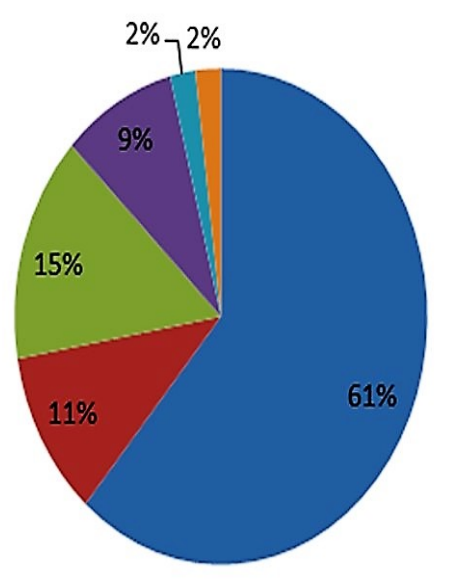

uLosmen
Kelontong
$\square$ Warung Nasi
$\square$ Rumah sebagai tempat
tinggal
$\square$ Outlet Kondom
$\square$ Balai RW

Tabel 6. Kategori dan Fungsi Bangunan di RW C, Sosrowijayan Kulon, Pasar Kembang, Malioboro Yogyakarta.

(Sumber: Data primer, Odam Asdi Artosa 2016)

Tabel 6 menunjukkan bahwa fungsi sebagian besar bangunan rumah dijadikan sebagai losmen langsiran. Seluruh penghuni yang mengelola losmen merupakan warga pendatang yang menyewa rumah dengan harga kurang lebih Rp4.000.000,00 per bulan . Harga sewa rumah yang dijadikan losmen langsiran dan tempat karaoke menyesuaikan luas bangunan rumah. Namun kisaran nominal yang banyak dijumpai kurang lebih Rp 4.000.000,00. Seperti contoh kasus losmen Mamah NVI dan Mamah RNI sebagaimana yang telah diungkapkan sebelumnya. 
Jurnal Pemikiran Sosiologi Volume 5 No. 1, 2018

Pekerja Migran dan Ekonomi Informal Ilegal (Prostitusi) di Wilayah Pasar Kembang, Yogyakarta

Odam Asdi Artosa

\begin{tabular}{|l|l|l|}
\hline Tahun & $\begin{array}{l}\text { Tarif Kamar } \\
\text { Langsiran }\end{array}$ & Tarif Pekerja Seks \\
\hline 1998 & Rp33,000,00 & Rp20,000,00-Rp30,000,00 \\
\hline $1999 \cdot 2002$ & Rp55,000,00 & Rp30,000,00-Rp50,000,00 \\
\hline $2003-2004$ & Rp10,000,00 & Rp50,000,00-Rp100,000,00 \\
\hline $2005-2008$ & Rp15,000,00 & Rp75,000,00-Rp100,000,00 \\
\hline $2009-2016$ & Rp220,000,00 & Rp100,000,00-Rp350,000,00 \\
\hline
\end{tabular}

Tabel 7, Perubahan Harga Losmen Langsiran dan Tarif Pekeria seks di Pasar Kembang (1998-2016)

\section{Sumber: Data primer, Odam Asdi Artoss 2016.}

Tabel 7 menunjukkan adanya perubahan nominal tarif dalam transaksi prostitusi yang mengindikasikan adanya perubahan tarif ngamar dan pekerja seks dari tahun ke tahun. Penghasilan dari pengelola losmen terbilang sedikit karena hanya seperlima dari penghasilan pekerja seks, tetapi nominal ini dapat membesar karena setiap losmen tidak hanya dihuni oleh satu orang pekerja seks saja.

Dari deskripsi hasil penelitian ini maka dapat dijabarkan bahwa kegiatan ekonomi informal khususnya yang berkaitan dengan perkembangan industri pariwisata di wilayah Malioboro khususnya di sub-distrik Pasar Kembang menunjukkan adanya konsistensi praktik ekonomi informal yang bersifat ilegal. Praktik prostitusi memang bukanlah suatu praktik ekonomi legal yang mendapatkan status jelas dalam sistem reproduksi ekonomi di Indonesia, meskipun upaya pemerintah untuk melokalisasikan praktik ini telah lama berlangsung, akan tetapi praktik ini tetap ada (eksis) dikarenakan keberadaannya juga turut mengembangkan praktik ekonomi informal lainnya termasuk jasa keamanan, dan pertumbuhan hunian tempat akomodasi wisata. Hal yang terpenting dari hasil penelitian ini adalah meskipun praktik ekonomi informal ini bersifat ilegal, akan tetapi tersirat bahwa pemerintah berusaha melakukan upaya untuk tetap mengontrol praktik ini terutama dalam penanggulangan penyakit seksual menular yang berbahaya. Para pekerja seksual yang terlibat maupun jejaring aktor yang mendukung usaha praktik ekonomi informal ilegal inipun pada gilirannya menyadari betul pentingnya upaya pencegahan penyakit seksual menular yang berbahaya. Hal ini nampak pada keberadaan beberapa outlet kondom yang sebelumnya di masa lalu tidak pernah tersedia dan karenanya praktik ini bukan hanya rentan berisiko melainkan juga malah akan menambah beban sosial bagi para pelakunya. Data penelitian menunjukkan bahwa praktik ini dijalankan oleh kebanyakan pekerja migran dari luar kota Yogyakarta juga hanya menghasilkan pendapatan yang tidak seberapa. Akan tetapi 'keberadaan praktik prostitusi' itu sendiri justru malah mengembangkan praktikpraktik ekonomi informal lainnya yang sebenarnya telah melembaga secara kultural di Jawa, termasuk di Yogyakarta.

\section{Interaksi Sosial Pekerja Migran dan Aktivitas Sektor Informal Ilegal di Pasar Kembang}

Interaksi sosial merupakan syarat utama terjadinya aktivitas-aktivitas sosial (Soekanto, 2012:55). Soekanto (2012:56) menilai bahwa interaksi dapat menunjukkan motif sesungguhnya manakala terjadi benturan nilai-nilai sosial. Oleh karena itu, simbol seperti batas wilayah, kesepakatan nilai, dan toleransi merupakan bagian dari proses interaksi. 
Jurnal Pemikiran Sosiologi Volume 5 No. 1, 2018

Pekerja Migran dan Ekonomi Informal Ilegal (Prostitusi) di Wilayah Pasar Kembang, Yogyakarta

Odam Asdi Artosa

Pada bagian ini digambarkan dinamika interaksi sosial ekonomi pelaku sektor informal ilegal di Pasar Kembang.

Sebagai sebuah wilayah yang memiliki lingkungan prostitusi, Pasar Kembang pada dasarnya tersegregasi dalam batas wilayah fisik yang memisahkan antara Sosrowijayan Wetan dan Sosrowijayan Kulon. Segregasi diartikan oleh Gottdiener dan Hutchison (dalam Wulangsari 2014), sebagai dorongan faktor sosial, budaya dan ekonomi yang membentuk perilaku sosial untuk menentukan lokasi tempat tinggal. Awal terjadinya pemisahan ini disebabkan oleh faktor sejarah. Selanjutnya, proses transformasi sosial menciptakan ruang yang dilandasi nilai dari masing-masing masyarakat. Nilai ini melekat sebagai identitas masyarakat dalam mencipatakan ruang masing-masing. Menurut Lefebvre (dikutip oleh Paturusi 2016:57), ruang sosial (conceived space) adalah ruang yang dibentuk akibat interaksi penduduk. Oleh karena itu, ruang yang tercipta mengukuhkan segregasi antara Sosrowijayan Kulon dan Sosrowijayan Wetan. Saat ini, segregasi antara wilayah Sosrowijayan Wetan dan Sosrowijayan Kulon dibedakan dengan komoditas yang diperdagangkan.

Di sisi lain, mayoritas warga asli Kampung Sosrowijayan Kulon berpindah ke luar kampung karena kehidupan disana sudah didominasi dengan kehidupan prostitusi. Menurut Amalia (2013), ada beberapa faktor yang menyebabkan warga asli menyewakan rumahnya ke pengelola losmen, yaitu faktor kesehatan, lingkungan sosial dan faktor ekonomi. Warga di Sosrowijayan Kulon tidak mau lokasinya disamakan dengan lokalisasi pada umumnya. Hal ini dijelaskan oleh ketua RW 03 Sosrowijayan Kulon, Bapak SRJ yang mengatakan bahwa pemerintah tidak memiliki kewenangan untuk membubarkan kegiatan prostitusi disana karena dari awal Sosrowijayan Kulon bukanlah tempat yang dilegalkan untuk lokalisasi. Lokalisasi dapat dibubarkan apabila pemerintah memberikan izin sebagai tempat lokalisasi dan menarik izin resmi yang telah diberikan itu. Oleh karena itu, menurut Bapak SRJ, wilayahnya itu adalah kampung biasa karena tidak memiliki izin lokalisasi, meskipun di sana terdapat aktivitas lokalisasi. Selain itu, Sosrowijayan Kulon merupakan perkampungan yang berdiri di atas tanah asli milik warga.

Keberadaan kegiatan prostitusi yang ada di Sosrowijayan Kulon membuat warga lain di kampung sebelahnya merasa waspada. Pagar pembatas antara Sosrowijayan Wetan dan Sosrowijayan Kulon merefleksikan demarkasi antara keduanya. Secara administratif, pagar pembatas digunakan untuk membedakan wilayah RW 02 Sosrowijayan Wetan dan RW 03 Sosrowijayan Kulon. Namun, alasan utama dibangunnya pagar pembatas dengan sistem bukatutup ini adalah masalah keamanan. Nilai sosial yang tercermin dari waktu buka dan tutup pagar ini merupakan negoisasi ruang untuk kepentingan, misalnya ibadah. Pagar sengaja dibuka pada jam 03.00 WIB untuk menghormati warga yang ingin beribadah.

Interaksi dalam sebuah masyarakat merupakan hal yang umum terjadi. Mead dalam Ritzer (2012:596) berpendapat bahwa interaksi merupakan kemampuan aktor dalam menafsirkan dunia sosialnya. Dalam konteks ini, aktor-aktor tersebut ialah para pelaku sektor informal ilegal yang terdapat di Pasar Kembang. Soekanto (dalam Firdaus 2015:3), menjelaskan syarat adanya 
Jurnal Pemikiran Sosiologi Volume 5 No. 1, 2018

Pekerja Migran dan Ekonomi Informal Ilegal (Prostitusi) di Wilayah Pasar Kembang, Yogyakarta

Odam Asdi Artosa

interaksi sosial yaitu: adanya kontak sosial dan komunikasi. Artinya, setiap pelaku sektor informal ilegal di Pasar Kembang dapat dikatakan melakukan interaksi sosial ketika mereka melakukan bentukbentuk tindakan komunikasi. Implementasi tersebut dapat terlihat dengan adanya keterkaitan yang saling membutuhkan antara pelaku sektor informal ilegal. Misalnya, seorang pekerja seks yang membutuhkan keberadaan toko kelontong untuk memenuhi kebutuhannya, kemudian, seorang pengunjung prostitusi yang membutuhkan jasa juru parkir.

Untuk memahami interaksi antara pelaku sektor informal ilegal, diperlukan pengkajian terhadap kondisi sosial masing-masing wilayah. Ruang sosial merupakan tempat untuk mengembangkan dan menginternalisasi nilai-nilai yang dipandang baik atau buruk tergantung pada suatu individu berada. Menariknya, meskipun segregasi masih terjadi di Pasar Kembang, interaksi antara kedua warganya berjalan cukup baik, sehingga memberikan dampakdampak ekonomi bagi warga lainnya dengan perputaran uang yang cukup besar (Mudjijono, 2005:110). Sejauh ini perputaran uang di Pasar Kembang mampu memberikan limpahan kepada para pelakunya.

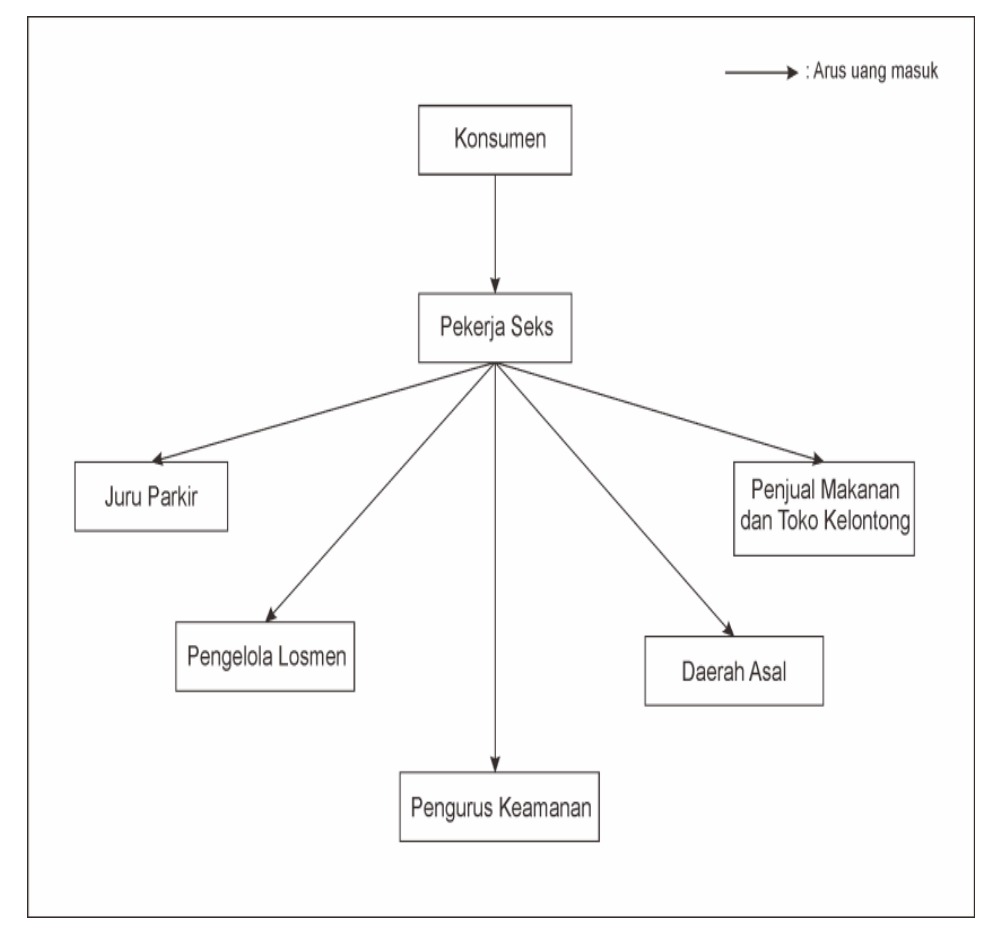

Gambar 2. Skema Interaksi sosial ekonomi sektor informal ilegal di Pasar Kembang.

(Sumber: Data primer, Odam Asdi Artosa 2016)

Gambar 2 menunjukkan bahwa pola interaksi yang dilakukan oleh pekerja seks mampu melibatkan banyak pihak. Artinya, kegiatan prostitusi telah menjadi jantung kehidupan di Pasar Kembang, baik pelaku sektor informal ilegal dan masyarakat yang membuka usaha. Di sisi lain, pelaku sektor informal ilegal dan pelaku usaha kecil saling membutuhkan untuk pemenuhan kebutuhan hidupnya. Berdasarkan penjelasan Ibu NVI, ia tidak mengalami diskriminasi dan sejenisnya ketika pergi ke Kampung Sosrowijayan Wetan. Menurutnya, basis yang dijalankan oleh masing-masing pelaku usaha hanya bersifat transaksional ekonomi semata, tanpa memandang status yang disandang oleh siapapun. Kasus tersebut berbeda dengan pendapat Prastya and Darma (2011:57) bahwa pekerja seks rawan dengan diskriminasi karena norma sosial dan agama telah diyakini kebenarannya oleh masyarakat 
Jurnal Pemikiran Sosiologi Volume 5 No. 1, 2018

Pekerja Migran dan Ekonomi Informal Ilegal (Prostitusi) di Wilayah Pasar Kembang, Yogyakarta

Odam Asdi Artosa

sehingga tidak ada toleransi untuk setiap kegiatan prostitusi. Meskipun keduanya dipisahkan secara geografis dan membentuk demarkasi antar wilayah, masyarakat Sosrowijayan Kulon dan Wetan tetap menjalin interaksi dengan baik. Hal ini ditunjukkan dari cara mereka membangun interaksi yang konstruktif yaitu saling memberikan toleransi yang tinggi.

Pasar Kembang yang merupakan icon sekaligus trademark dari Malioboro yang sangat dikenal masyarakat diharapkan mampu memberikan gambaran terhadap kemungkinan yang dapat terjadi pada sektor informal. Pertama, interaksi sosial ekonomi dapat terus berjalan dengan baik, namun rawan dengan konflik. Sejauh ini, interaksi sosial ekonomi di Pasar Kembang berjalan dengan baik. Namun, interaksi yang baik belum tentu memberikan hubungan yang harmonis terus menerus. Menurut Soekanto (2012:60) interaksi didasarkan pada kontak sosial yang dilakukan tiap aktor, kontak sosial memiliki dua kecenderungan yaitu: positif dan negatif. Kontak sosial yang dilakukan masyarakat menjadi penentu dari sumber datangnya konflik. Contohnya, kesepakatan losmen untuk pelayanan seks hanya dilakukan di Kulon. Hal ini dapat menjadi konflik apabila salah satu aktor melakukan kontak sosial yang melanggar kesepakatan sosial yang telah disetujui. Kedua, rencana relokasi Pasar Kembang mampu menjadi ancaman bagi sektor informal ilegal yang ada disana. Pasalnya, apabila melihat beberapa sisi di kawasan Malioboro saat ini, beberapa diantaranya sudah dilakukan relokasi. Beberapa saat yang lalu, Menteri Sosial Khofifah Indar Parawansa mengeluarkan pernyataan bahwa Indonesia ditargetkan bebas dari prostitusi pada tahun 2019 (dikutip dari CNN,
2016). Khofifah menyatakan bahwa pekerja seks akan diberi Usaha Ekonomi Produktif (UEP) Rp3.000.000,00 per orang dan Jaminan Hidup (Jadup), sehingga total yang diperoleh tiap individu adalah Rp5.050.000,00 sebagai modal sosial. Selain itu, data menunjukkan bahwa saat ini sudah 160 lebih lokalisasi di Indonesia telah di tutup, dan hanya tersisa 33 lokalisasi (dikutip dari CNN, 2016). Dari jumlah sisa 33 lokalisasi ini, Pasar Kembang merupakan salah satunya.

Melihat kondisi yang telah ada, tampaknya jumlah jaminan hidup (jadup) tidak seimbang dengan dampak yang akan ditimbulkan. Adanya pembubaran lokalisasi dapat mengakibatkan dampak yang lebih buruk lagi. Selain itu, Sugiyono dkk (2015) berpendapat bahwa penutupan lokalisasi menjadi hal yang paling dikhawatirkan karena ketika lokalisasi ditutup, tidak ada lapangan kerja untuk menampung eks penghuni lokalisasi. Biasanya mantan penghuni lokalisasi mendapat stigma negatif oleh pemilik usaha. Implikasi, pekerja seks tidak kunjung mendapat pekerjaan baru, maka ia akan bekerja sebagai pekerja seks lagi di daerahdaerah dan tidak dapat dideteksi keberadaannya.

\section{E. Kesimpulan}

Pekerja seks dapat dikatakan menjadi komoditas utama dalam praktik ekonomi informal ilegal di Pasar Kembang. Munculnya sektor informal ilegal di Pasar Kembang merupakan bentuk dari dari keadaan urbanisasi berlebih, karena pelaku sektor informal ilegal di Pasar Kembang didominasi oleh warga luar daerah seperti Jepara dengan persentase 23\% dari total 283. Adanya prostitusi di Pasar Kembang menghidupkan usaha-usaha kecil lainnya, 
Jurnal Pemikiran Sosiologi Volume 5 No. 1, 2018

Pekerja Migran dan Ekonomi Informal Ilegal (Prostitusi) di Wilayah Pasar Kembang, Yogyakarta

Odam Asdi Artosa

karena dibalik interaksi ekonomi terdapat interaksi sosial yang didalamnya menyangkut relasi-relasi antar pelaku usaha. Misalnya interaksi antara pengunjung dengan pekerja seks dan pekerja seks dengan sektor informal lainnya.

Secara garis besar, interaksi pelaku sektor informal ilegal di Pasar Kembang berjalan dengan baik. Demarkasi batas wilayah fisik bukan sebuah simbol kontradiksi antara masyarakat dan pelaku sektor informal ilegal. Namun, lebih tepatnya adalah implementasi dari hasil interaksi yang mencapai kesepakatan bersama. Dinamika interaksi sosial ekonomi di Pasar Kembang sejatinya memang sudah terlembaga dengan baik, namun wacana relokasi dapat mengancam keberadaan sektor informal ilegal dan pelaku usaha lainnya. Apalagi, sektor informal ilegal di Pasar Kembang merupakan destinasi bagi tenaga kerja dari luar daerah, terutama pedesaan. Oleh karena itu, dibutuhkan pemerataan pembangunan, terutama di daerah pedesaan.

Perkembangan Pasar Kembang secara khusus dalam praktik prostitusi telah lama menyita perhatian tersendiri bagi pemerintah daerah sejak perkembangannya khususnya di masa pascakolonial hingga saat ini. Upaya yang dilakukan bukan hanya berkenaan dengan melahirkan beragam produk kebijakan pemerintah daerah yang bersifat legal semata, melainkan juga upaya-upaya yang bersifat kultural dengan melakukan sosialisasi khususnya tentang penyebaran penyakit seksual menular yang berbahaya. Di sisi lain, adanya segresasi sosial di wilayah sekitar Pasar Kembang menunjukkan adanya potensi konflik sosial yang sewaktu-waktu dapat terbuka menjadi konflik yang rentan dengan kekerasan dan bahkan kriminalitas. Oleh karena itu, interaksi antar warga yang tinggal di wilayah tersebut membutuhkan suatu mekanisme mediasi sosial dan budaya untuk menghindarkan adanya kemungkinan terbukanya konflik-konflik sosial akibat segregasi ekonomi-sosial-dan budaya di wilayah Pasar Kembang.

Upaya pembubaran lokalisasi praktik prostitusi dalam kenyataannya justru menimbulkan resiko sosial yang jauh lebih besar lagi. Hal ini dikarenakan banyak pekerja seks justru bekerja secara 'liar' sehingga tidak dapat diamati pola-pola aktivitasnya dan karenanya justru akan menimbulkan kerentanan baru dalam masalah sosial. Dengan kata lain, prostitusi adalah aktivitas produksi ekonomi yang bersifat 'purba' yaitu telah menyejarah dalam perkembangan peradaban kemanusiaan itu sendiri. Segencar apapun upaya yang bersifat moralis dan bersifat legal formal akan sulit untuk mengatasi praktik ekonomi ilegal yang mengkomodifikasikan khususnya tubuh perempuan dalam industri pariwisata dan khususnya industri hiburan dimanapun di seluruh dunia, termasuk di Indonesia, tak terkecuali di Yogyakarta. Dengan kata lain, upaya-upaya yang dapat dilakukan oleh warga masyarakat setempat untuk menanggulangi segregasi ekonomi dan budaya membutuhkan dukungan yang melibatkan bukan hanya peran pemerintah daerah semata melainkan juga elemen masyarakat sipil sehingga dapat menghindarkan terbukanya peluang-peluang bagi konflik kekerasan antar warga masyarakat yang berbeda-beda kelas sosial dan latar budayanya masing-masing, termasuk dalam perlindungan khususnya pada pekerja informal yang adalah para pekerja migran perempuan. Merekalah yang berada di dalam garis terdepan dalam menanggung semua risiko sosial, ekonomi, bahkan politik sebagai konsekuensi atas 
Jurnal Pemikiran Sosiologi Volume 5 No. 1, 2018

Pekerja Migran dan Ekonomi Informal Ilegal (Prostitusi) di Wilayah Pasar Kembang, Yogyakarta

Odam Asdi Artosa

praktik ekonomi informal ilegal ini. Padahal mereka yang menampuk keuntungan dari praktik ekonomi informal ilegal ini bukan hanya para pekerja seks itu semata-mata, melainkan jejaring pelaku yang terlibat di dalam perkembangan industri pariwisata dan hiburan.

\section{Daftar Pustaka}

\section{Sumber Buku \& Jurnal}

Amalia, A.S., 2013. “Dampak Lokalisasi Pekerja Seks Komersial (PSK) Terhadap Masyarakat Sekitar: Studi Kasus di Jalan Soekrno-Hatta Km.10 Desa Purwajaya Kabupaten Kutai Kartanegara". eJournal Administrasi Negara Vol. 1, No. 2, Hlm. 465-478.

BPS, 2012. Survei Sosial Ekonomi Nasional 2012: Keterangan Pokok Rumah Tangga dan Anggota Rumah Tangga. Jakarta: BPS.

Cornelius Prastya R. K., Darma, A., 2011. Dolly: Kisah Pilu Yang Terlewatkan. Yogyakarta: Pustaka Pena.

Effendi, T.N., 1995. Sumber Daya Manusia, Peluang Kerja dan Kemiskinan. Yogyakarta: Tiara Wacana.

Effendi, T.N., 1988. "Kesempatan Kerja Sektor Informal Di Daerah Perkotaan, Indonesia (Analisis Pertumbuhan dan Peranannya) $=$ Employment Opportunity in Informal Sector in the Urban Areas, Indonesia (The growth and role analysis)". Majalah Geografi Indonesia Vol. 1, No. 2, Hlm. 1-10.

Firdaus, R., n.d., 2015. "Interaksi Sosial Masyarakat Transmigrasi dengan Masyarakat Lokal di Desa Sungai Besar Kecamatan Matan Hilir Selatan Kabupaten Ketapang". Jurnal Sosiologi Vol. 3, No. 3, Hlm. 1-15.

Hardiman, F.B., 2010. Ruang Publik: Melacak Partisipasi Demokratis Dari Polis Sampai Cyberspace. Yogyakarta: Kanisius.

Issabela, N., Hendriani, W., 2010. "Resiliensi pada Keluarga yang Tinggal di Lingkungan Lokalisasi Dupak, Bangunsari”. INSAN Vol.
12, No. 3, Hlm. 176-186.

Koeswinarno, 2004. Hidup Sebagai Waria. Yogyakarta: PT LKiS Pelangi Aksara.

Manning, C., Effendi, T.N. (Eds.), 1985. Urbanisasi, Pengangguran, dan Sektor Informal di Kota. Jakarta: Gramedia.

Mudjijono, 2005. Sarkem: Reproduksi Sosial Pelacuran. Yogyakarta: UGM Press.

Nazara, S., 2010. Ekonomi Informal di Indonesia: Ukuran, Komposisi dan Evolusi. Jakarta: ILO.

Paturusi, S.A., 2016. "Segregasi Ruang Sosial Antara Pendatang dengan Penduduk Asli pada Permukiman Perkotaan di Denpasar". Jurnal Kajian Bali Vol. 6, No. 2, Hlm. 57-78.

Ritzer, G., 2012. Teori Sosiologi, Yogyakarta: Pustaka Pelajar.

Siswanto, B.B., 2013. Prostitusi di Sosrowijayan Yogyakarta: Studi Interaksi Pekerja Seks Komersial Pasar Kembang dengan Masyarakat Sosrowijayan. Yogyakarta: UIN Sunan Kalijaga.

Soekanto, S., 2012. Sosiologi Suatu Pengantar. Jakarta: Rajawali Pers.

Sugiyono, Inayah, N., Biati, L., Andriani, Z.Z.D., Nasrullah, M.A., 2015. "Dampak Sosial Penutupan Lokalisasi di Kabupaten Banyuwangi: Studi Kasus Tentang Faktor Penyebab Mantan PSK Kembali Bekerja Di Lokalisasi Turian Purwoharjo Banyuwangi". Jurnal Hukum Islam, Ekonomi dan BisnisVol. 1, No.1, Hlm. 1-16.

Usman, S., 2015. Esai-Esai Sosiologi: Perubahan Sosial. Yogyakarta: Pustaka Pelajar.

Varshney, A., 1993. Beyond Urban Bias. New York: Routledge.

Wulangsari, A., 2014. "Tipologi Segregasi Permukiman berdasarkan Faktor dan Pola Permukiman di Solo Baru, Sukoharjo". Jurnal Pembangunan Wilayah dan Kota Vol. 10, No. 4, HIm. 387-399. 
Jurnal Pemikiran Sosiologi Volume 5 No. 1, 2018

Pekerja Migran dan Ekonomi Informal Ilegal (Prostitusi) di Wilayah Pasar Kembang, Yogyakarta

Odam Asdi Artosa

\section{Sumber Website}

Badan Pusat Statistik. 2016. Konsep Tenaga Kerja. (https://www.bps.go.id/Subjek/view/id/6) Diakses tanggal 29 Mei 2016.

Cahya, K.D., 2016. Saat Penggusuran Kalijodo Tanpa Daeng Azis. Kompas 27 Februari 2016 (http://megapolitan.kompas.com/read/201 6/02/27/06290061/Saat.Penggusuran.Kali jodo.Tanpa.Daeng.Azis) Diakses tanggal 09 Januari 2017.

Ferryardiyanto, 2013. Sejarah Jalur Trem Yogyakarta - Brosot (1895 - 1976) (http://kebudayaan.kemdikbud.go.id/bpcb yogyakarta/2013/08/22/sejarah-jalurtrem-yogyakarta-brosot-1895-1976/).

Diakses tanggal 28 Oktober 2016.

Mubyarto, 2002. Ekonomi Rakyat Indonesia Pasca Krismon.

(http://jer.mubyarto.org/edisi_9/artikel_1. htm ) Diakses tanggal 1 September 2016.

\section{Sumber Skripsi (Tidak dipublikasikan)}

Artosa, Odam Asdi. 2016. "Dinamika Interaksi Sosial-Ekonomi Sektor Informal Tidak Sah di Pasar Kembang". Skripsi. Departemen Sosiologi. Universitas Gadjah Mada. 